\title{
Concept of Sustainable Housing Design and Material construction in the Tropics
}

\author{
Putri Suryandari ${ }^{1}$ \\ \{putri.suryandari@budiluhur.ac.id ${ }^{1}$ \} \\ Architecture Dept., Faculty of Engineering, Budi Luhur University, Jl. Ciledug Raya, Jakarta, \\ Indonesia $^{1}$
}

\begin{abstract}
Currently environmental conditions at the local to international levels, are experiencing poor quality degradation. The development of construction materials that continue to be produced around the world, became one of the causes of environmental degradation. Current construction materials tend to be used throughout the world, requiring a lot of natural resources to be explored on a large scale. The balance of nature is disturbed due to the exploration of vast natural resources. This study aims to obtain alternative design and construction materials for housing in the tropics that can reduce the problem of environmental degradation. The solution in obtaining residential design in a sustainable tropical region uses the principles of green architectural concepts that unite the philosophy of local building tradition with little modern material
\end{abstract}

Keywords: mix and match, traditional, sustainability, modern construction, housing.

\section{Introduction}

Sustainable Architecture is architecturein which the design and construction system, can continue to be used from time to time. The architectural design and construction materials may differ in regions with different geographical and sub-natural conditions [1].

Architecture of housing in Indonesia, especially after independence Indonesia, shows that building for residential purpose are not based on regional and social needs. Studies indicate that some new development housing was left by inhabitant because floods, no match façade orientation with livelihood, type of house and/or different habit of new housing space. It is tending towards modern construction and architecture due to that the old and historical architecture is being replaced by modern building.

The consequences of centralization regulation urban development housing show that the houses were built with the nearest available material, and often tradition and/or culture govern construction-materials. So that whole towns, areas, countries or even states/countries built up of one main type of material.

In the tropics area likes Indonesia, it is particular different settlement. Traditionally wood has been used as major element of building construction. The type, shape, structure, ventilation and waste disposal depend upon many factors, depending upon the culture, regional area, religion, topography, geographical conditions. The development of new building material, methodologies and technologies not only costly but also sometimes doesn't match the tropic. Looking cost and environmental factors, more attention need to be drawn to 
develop some optimization of use of combination traditional and modern construction technology so that, not only sustainability may be attained in building construction but traditional architecture can also be maintained. But optimization of mixing traditional and modern construction should be done based upon the natural disaster like earthquake, flood, volcano and fires which frequently occur in the wide spread region of the country. Traditional buildings are not costly and environmental friendly but sometimes they are not able to resist the natural disasters occurring in this region. The extensive uses of natural resources are unbalancing the natural ecosystem equilibrium, which result in environmental degradation, globalwarming, ozone depletion and rapid growth ingreenhouse gases.

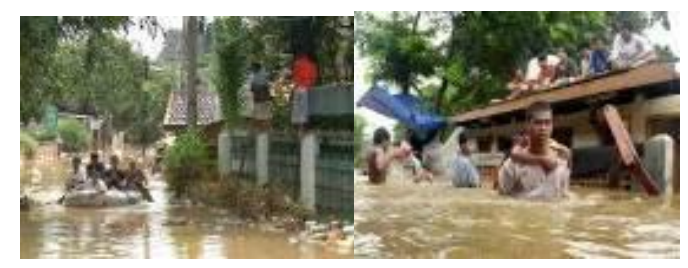

Fig. 1 \& 2. Flood in Jakarta, February 2007. For about $60 \%$ Land use in Jakarta closed by floods.

History shows that in Indonesia natural disasters such as earthquake, volcanic eruption, floods, landslides, dryness, or the forest fire has been periodically occurring in the region. The example of one of the worst natural disasters in the last 10 years was the flood which came in Jakarta, in February 2007. About 60\% land and building in Jakarta were affected. Residential and other buildings were also badly effected from partially to fully damage. In some regions likes Ciledug Indah Village water reached up to the height of 4 meter from the ground.

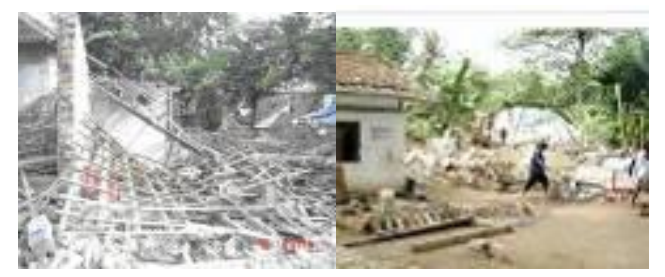

Fig. 3 \& 4. Destruction under Earthquake in Bantul,Yogyakarta (May-2006)

Another example of natural disaster is Earthquake occurred in Bantul, Yogyakarta (May2006). Even though the intensity of earthquake is not too high but death toll counted nearly 6000 causalities. Most of the people were buried under collapsed building. The building collapsed during earth quake was brick made with low strength (quality) cement-sand mortar. These structures were absolutely not resistant to earthquake. In many of the regions the buildings too dense, this multiplies the impact of earthquake. This also shows the ill planning in housing sector with ignorable regulation of building department. There is also need of restructuring of building code [2]. 
According to the Chief of public housing of Indonesian Cares (MP3I), Dr. Eng. Aca Sugandi, to save this country from natural disasters we have tomaintain the environmental and ecosystem at its natural balance. On the other hand, it is also required to revive the countryside and urban area housing planning [3]. Prof. Dr. Ing. Uras Siahaan lic.rer.reg (2006), said that the traditional housing settlement culture conserved resources, environment and natural ecosystem. The geographical condition gave birth to the housing forms that fit to the condition of regions. The natural condition of Indonesia is often threatened by the earthquake, volcano eruption, floods and floods waves on the strand, so that construction form and development system of the building have to able to handle them [4].

The practice of modern architectural development leads to environmental and social crises around the world. Hence the concept of "Sustainability" emerged in the early 1970s in response to the phenomenon.Sustainability represents a balance that accommodates human needs without diminishing the health and productivity of natural systems [5]. According to AIA (American Institute of Architecture) sustainability is the ability of society through exhaustion or overloading of the key resources on which that system depends [6].

\section{Research objective}

- To discuss the matching concept of traditional housing in Indonesia with sustainable architecture concept.

- To generate a relationship between traditional and modern housing (architecture) so that a balance can be obtained in terms of ecosystem, natural resources used, environment friendly construction.

- To discuss the acceptability of innovated mix and match techniques of traditional culture and modern technology of construction to provide more safer, economical, sustainable and comfortable solution.

\section{Research Methodology}

Formulation of problem used Formal Analog, because the topics problems come from previous theory and research. Formal Analog is a problems invention taken from dissimilar science and applies it to research area. Pursuant to research operational system, research type used by The Descriptive Survey Method, the research hit data obtained from observation. Pursuant to procedure of research step, method of research usage is qualitative, with Deductive Empirical method. 


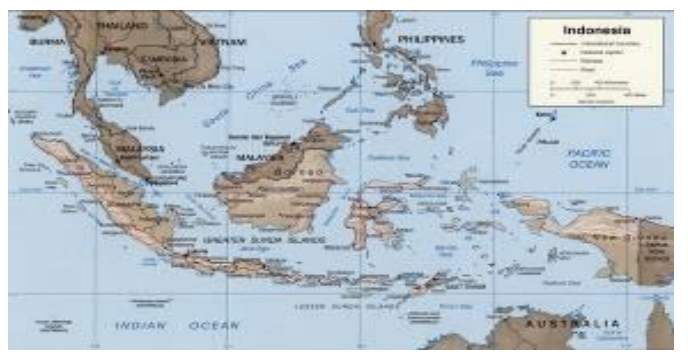

Fig. 6. Map of Indonesia showing different provinces and islands.

This Research aspect is sustainable traditional housing settlement in the tropics area concerning in Indonesia. Population used is going concerns about traditional housing in Indonesia. The variables are concern in sustainable construction, material, structure, form of building and comfort, on traditional and modern technology.

Analysis method is for knowing standard of Sustainable Housing for Tropics area by innovated mix and match techniques of traditional culture and modern technology.

\section{History of Indonesian architecture}

Indonesia is the largest archipelago country in the world, has 17,508 islands, 11,508 islands are still uninhabited and only 6000 islands inhabited by the inhabitants [7]. These islands are spread all over the equator. Java, Sumatra, Kalimantan (Borneo), Papua, and Sulawesi are the five largest islands in Indonesia. Indonesia is bordered by Malaysia located on the island of Kalimantan, Papua New Guinea on the island of New Guinea, and East Timor on the island of Timor. As a large country, tropical climate, and geographical conditions, biodiversity levels in this country occupy the second highest position in the world after Brazil [8]. 60\% of Indonesia is Forest [9]. Indonesia has 300 tribesand 742 different languages and dialects, each growing with cultural differences over the centuries, the country is also influenced by the Arabs, Chinese, Malays, and Europeans [10].

The diversity of Indonesian Architectural forms isa reflection of the cultural, historical and geographical influences that make up the whole of Indonesia. Prominent changes in style and engineering of buildings, many influenced by invaders, merchants, invaders and missionaries.Traditionally, the most significant influence has been Indian, but Chinese, Arab, and more recently. European influences which have been important.

There are three vital impacts seen on the Indonesian architecture listed below.1. Religion 2. Regional 3. Colonial

Traditional Indonesian architecture is influenced by many factors of religion and belief. For example, in the 8th to 14th centuries the traditional architectural style was mostly Hindustyle architecture, this was due to the influence of the Hindu-Buddhist kingdom which was the greatest kingdom of the time.

In the fifteenth century, Islam has become the dominant religion in Indonesia, especially in the two largest islands of Java and Sumatra. Foreign influences in Islamic architecture, absorbed and interpreted into Javanese / Indonesian. The mosque was built at that time, many featuring ornament that has a Hindu style, Buddhist is also Chinese. For decades, during Indonesian Independence the mosque in Indonesia was then built in a style taken from global Islamic forms which is a reflection of the tomb. 
Indonesia's climate condition is a humid tropical climate. It has high rainfall, so traditional buildings generally have steep roofs and long overhangs. The houses stand on wooden and stones pillars ( 1 to $4 \mathrm{~m}$ ) for air circulation and reduce the high humidity factor. Against high / hot temperatures throughout the year the house, built with a long overhang on the roof.

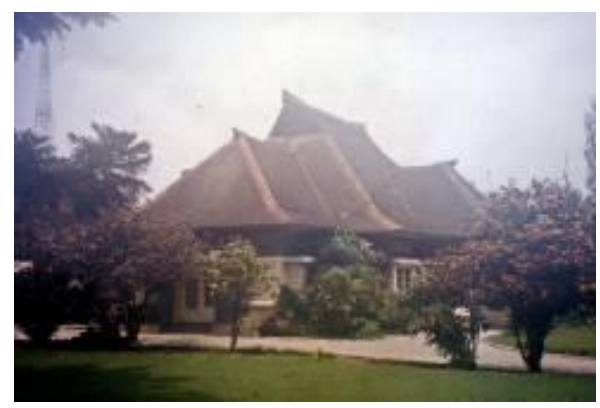

Fig. 7. This pre-war Bandung home is an example of 20th century Indonesian Dutch Colonial styles.

The 16th and 17th centuries saw the arrival of European buildings in Indonesia, is to use the stone in the system of construction. The construction system in Indonesia has always used wood and its supporters, except for forms that except for the forms that follow the religion and the buildings of the Royal palaces. In the 17th - 18th century, the first large settlement of the Dutch (Colonial) period, Batavia, used brick in its construction system. The colonialists did not adapt the European architectural style to the tropical climate in Indonesia, for nearly two centuries. In Batavia, for example, they built low waterways facing small and poorly ventilated, poorly ventilated, mostly Chinese-Dutch hybrids. Although, the series houses, drains and closed walls were first considered as protection against tropical diseases originating from the tropical air. Years later the Dutch learned to adjust their architectural style with local building features (long roofs, porches, porticos, large windows and ventilation holes) [11].

One of the first buildings in Indonesia that combine elements of Indonesian architecture with colonial, and try to adapt to climate is, Indo-European hybrid villa in the 19th century. The basic form is Javanese architecture, such as the longitudinal space and the use of Joglo and Limasan roof structures, but incorporates European decorative elements such as the neoclassical columns around the inner verandas. In the 20th century developed Indo-European houses, in fact it is a European-style Indonesian house. The trend that developed at the time was Modern Art Deco style, expressed by European buildings that incorporate some traditional Indonesian decorations and elements (examples of high roofed buildings with Javanese ornament details). Practice Hybrid Indonesia - Europe that existed previously is to respond to the climate of Indonesia, especially the hanging roof, windows and ventilation on the larger wall.

\section{Matching Concepts of Green Architecture Traditional Housing in Indonesia with Sustainable Architecture}

Sustainable architecture applies techniques of sustainable design to architecture. It is related to the concept of green building (or green architecture). Green Architecture can be 
described as the architectural development and environment that has many typologies of architecture which could conserve resources, environment and natural ecosystem [6]

Characteristics and classifications of Traditional housing in humid tropic climate like Indonesia, have matching concept with sustainable architectural concept, among others:

1. Use Natural Material and Local material

2. Keep cool the house with raised-floor construction, Steep Roof and long over hang

3. Lay out plan increasing a sun lighting

4. Small is beautiful and Energy efficiency

\subsection{Use Natural Material and Local material}

Traditionally in Indonesia, wooden buildings have been constructing. The type and use of wood are lies in wide range from hard wood to bamboos. The use of extensive wood in housing sector is the main cause of deforestation in the country which caused frequent floods and erosion of top soil in to river system. The traditional construction was fit for earth quake resistance, because of their resistance to horizontal loading (earthquake waves). Example of a five meter high traditional warehouses and barns made of bamboo and sugarcane leaves in the badly hit Bantul district in Yogyakarta has put here, which still stands in its original position after the earthquake (May, 2006) while modern buildings in the same region were ruined [12]. However, bamboo is not only strong and flexible material, it aesthetically appealing.

The material was easy to obtain and easily replaced when aged or damaged by weather condition.

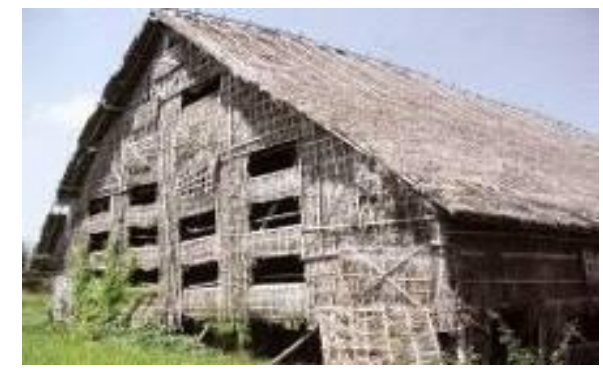

Fig. 8. Traditional warehouse in Bantul which is highly resistant to the earthquakes.

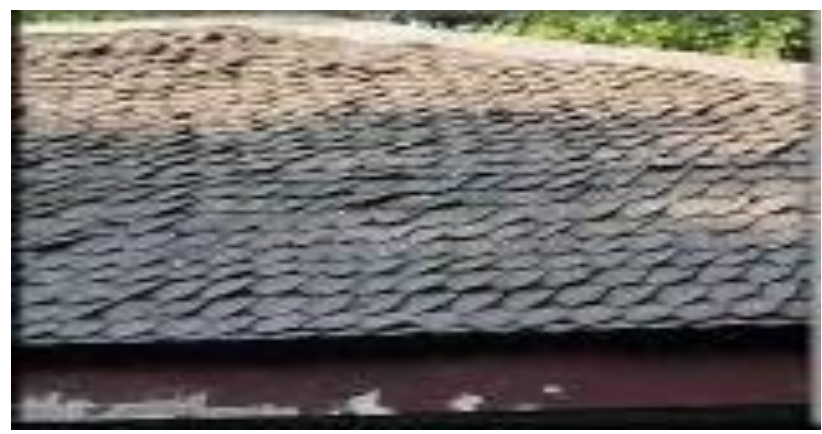

Fig. 9. 35 year old roof in Surabaya. 
Indonesia traditional houses use a lot of iron wood shingle or known as shingle, as a roofing material. Shingle comes from Borneo and has been used for hundreds of years by locals. Dutch colonists who see and know the power of this material then introduce the wider community throughout the archipelago. The shingles that come from Ulin wood are introduced in the name of Iron Wood, is the wood that has the longest and strongest stamina in the world.The Dutch colonials introduced them to the rest of the archipelago and they are now found on many large government buildings as well as high class houses. It has a serviceable lifespan of at least thirty years. Alang-alang thatching has been used in Indonesia for hundreds of years on the islands of Bali, Lombok, Sumbawa, Timor and Sumba as a traditional system of roofing. There are slight variations in the application of the material throughout these different places but by far the neatest and strongest form is found in Bali [13].

\subsection{Keep Cool the House with Raised-floor Construction, Steep Roof and Long over Hang}

Climate condition is Humid-Tropics Climate which the high temperature all over the year. A House with raised-floor construction can control the room temperature to keep its cool usage natural ventilation system. The raised-floor construction, make add space behind the floor. The air circulation can flow and influence a house temperature to keep cool. More advantage can find if floor is using by wood material. So that, wind will acquire the sixth side of house and reduce high temperature that influence from around the village.

Almost all of Architecture Traditional housing in Indonesia especially Sumatra, Sulawesi, Aceh, Kalimantan, Riau and Betawi use raised-floor construction. The first floor is functions especially for breeding animals, wild animal, climate condition and disaster. The construction of living space there are two alternatives; either the beams of the raised floor are mortised through posts reaching up to the roof $-\mathrm{H}$ frame- or alternatively, the foundation elements do not reach above floor level and carry a box frame/ construction (ex:Toraja House, Sulawesi house, Aceh House shown by Figure $10 \& 11$ [14].

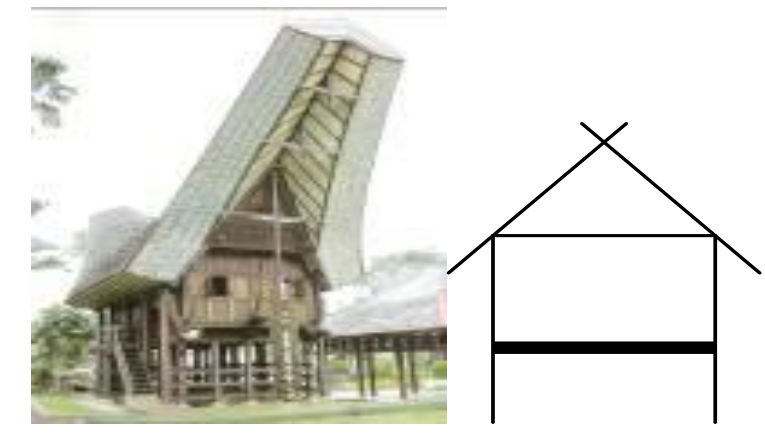

Fig. 10 \& 11. Sulawesi Tenggarahouse, $\mathrm{H}$ frame construction.

Again two alternatives; either the beams of the raised floor are mortised through posts reaching up to the roof $-\mathrm{H}$ frame- or alternatively, the foundation elements do not reach above floor level and carry a box frame/ construction (ex:Toraja House, Sulawesi house, Aceh House) shown by Figure 10 \&11 [14]. 
On the other hand, traditional house roof in Indonesia also varies by form. All varies also construction by wood. Varies roof from Java are Kampong Trajumas roof, Kampung Doro gepak roof, Limasan roof and Joglo roof. Against heavy Rainfall, it has steep roof and long overhang. The high humidity will be reduces through good air circulation.

Kampong Trajumas roof, have open air circulation for ventilation in front to back the house. Kampung Doro gepak roof have steep roof and open air circulation also in front to the back house, but less than trajumas. Limasan roofs, has closely roof and no open air circulation. Joglo roofs have steep roof andopen air circulation from inclination of steep and sloping roof.

\subsection{Lay out Plan to Increase the Effect of the Sunlight}

The main arrangement of Javanese houses is to use the principle of centrality and linearity. Pendopo or open center space represents the concept of centrality, which is focused in the middle.

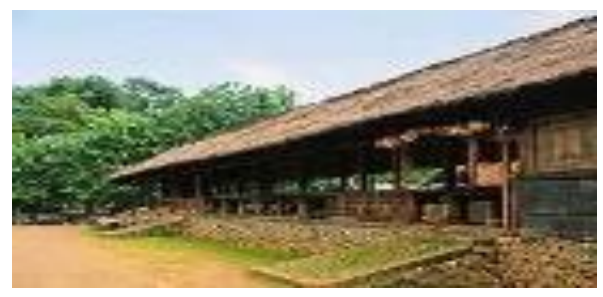

Fig. 13. Pawongan from the Panglipuran village house, one of traditional housing in Bali.

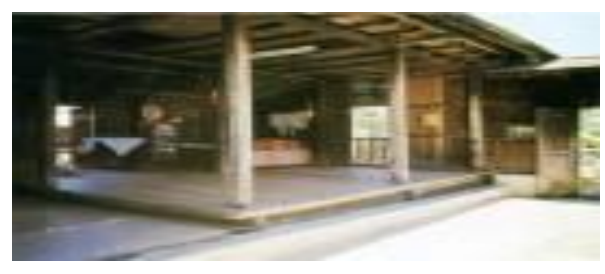

Fig. 14. Bali traditional house in Tenganan village basically formed of open wall architecture, which consists of a wall compound and court yard.

Overall the house, the duality of the pavilion and the residence is connected to the hallway. Dominant linearity with respect to the ultimate place in the house, located in the middle behind the dwelling, like a bed, a dining area and a kitchen. A further distinction between the public and private spaces of residence is the existence of an open pavilion where guests are formally welcomed. Around the basic structure of this house, other rooms such as kitchens, bathrooms, living rooms and dining rooms can be found. All units are encircled by fences.

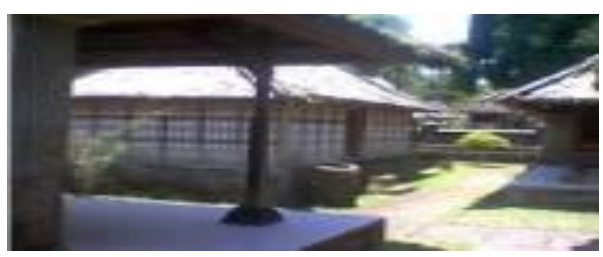

Fig. 15. Bali traditional house in Panglipuran. 
Building orientation of Javanese houses is to fit in with point of the compass, North and South or West and East. North and South are upstream towards the sea. West and East are upstream towards the mountain. In the East there are Semeru and Merbabu mountains, whereas in the West is Merapi mountain.

Orientation direction to East and West is influenced by the people in habitant livelihood as afarmer. They use in front and the back of the house to dry their rice-plant. North and East orientation are influenced by their traditional beliefs with the goddess, especially Nyi Roro Kidul from East.

Balinese residence is also a form of architecture that has many buildings. The orientation of the front of the house overlooking the sacred mountain of Mount Agung, has an important meaning [15]. This direction is considered sacred, while the opposite is dirty (not sacred). The area of the house is divided into two sides and three sections, the first side to the mountain (head), ground (body), and sea (feet), and, on the other side to the sun, rise (head), peak (body), and setting. This combination of both sides produces nine directions where the combination of mountains / sunrise (head / head) is the most sacred and sacred-oriented mountain. The combination of sea / sunset setting (feet) is the profane. This means that the house of Bali is dominated by anthropomorphic and cosmic principles combined in gradations from the sacred to the profane. (Nas 1995).

However the Javanese and Bali house are basically formed by open wall architecture, which consists of the wall compound and have an open space. Centrality room and open space can give the sunlight entirety of a house. The orientations of traditional houses usually have connected with their fences and livelihood and to fit in with point of compass.

\subsection{Small is Beautiful and Energy Efficiency}

The uniqueness of housing in Indonesia is to have many buildings (pavilion) consisting of several small units with different functions, such as places to receive guests where to eat, sleep temps, kitchens and baths, for example there are at home Bali and Java. Some of the housing on the other island consists of an elongated building.

Building a house consisting of several small building units, the goal is to avoid humidity and circulation, it is suitable for humid tropical climate like in Indonesia. Cross ventilation and maximizing sunlight are the main goals of building small buildings in the home. Sunlight can heat the four sides of the wall to the maximum, thus preventing moisture. Small buildings also mean material efficiency that can help reduce environmental problems. In addition, in general the advantage is to facilitate the treatment.

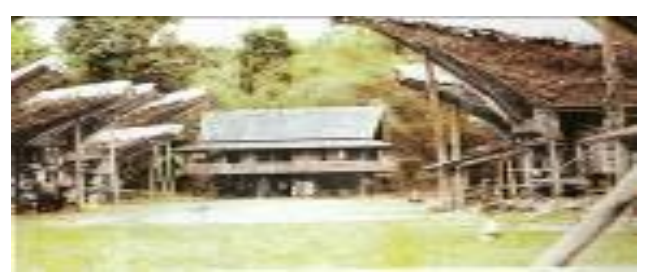

Fig. 16. Toraja house is compound system.

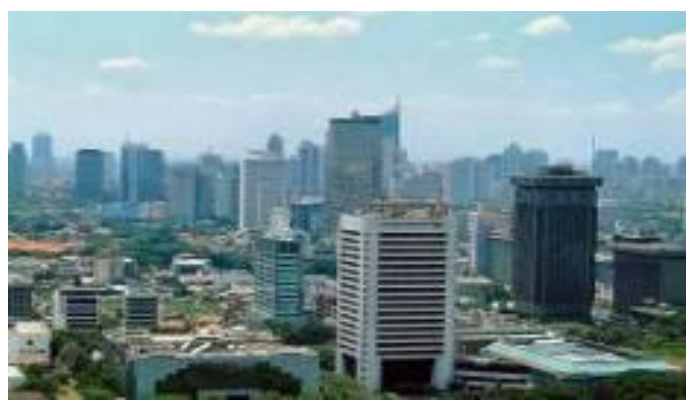

Fig. 17. A view of modern architecture style of Indonesian Architecture. 


\section{Unity the Concept of traditional and modern technology towards Sustainable Architecture Housing in Indonesia}

Traditional architecture are disappearing and being replaced by modern civilization. Following Indonesian independence, a number of government-funded major projects were undertaken in the modernist style, particularly in the capital Jakarta. Figure-19 shows the modern view of Indonesian architecture. Reflecting President Sukarno's political views, who were civil, engineer by himself, which the architecture is openly nationalistic and strives to show the new nation's pride in itself. "Let us prove that we can also build the country like the Europeans and Americans do because we are equal" Soekarno [16].

Native architecture was arguably more influenced by the new European ideas than colonial architecture was influenced by Indonesian styles; and these Western elements continue to be a dominantinfluence on Indonesia's built environment today Economic stability and growth in the 1970s, 1980s and 1990s saw large construction booms and major changes to Indonesian architecture.

According to Prof. Dr. Ir. Hasan Purbo (2006), translations and combinations of traditional architectural concepts into modern technology could be described below:

- Modern architecture technology as a mean of construction system

- Concepts of traditional architecture are applied as the meaningful and spiritual design concept.

- The decision making in the form, hierarchy, pattern, and the role of design will be taken from the traditional concepts.

- The spatial system will be reformed, adjusted with nowadays needs. But the reformation shouldn't opposite the traditional architecture concepts of space.

The following are considered in during construction of Modern house in Indonesia.

- Compatibility to tropical environment

- Durability, Safety and Comfort

- Thermal Comfort

- Resistant to Natural Disaster

- Cost factors

- Traditional and Spiritual values

Now modern housing needs technology for comfortable housing and increasing the quality of life. The concepts of traditional green architectural housing in Indonesia have also its weakness. Compounds building which consist of several building needs more space and large area. At present the land value is expensive and needs much money to pay the larger land area for houses. Using natural material can't save the forest, because it is the main cause of deforestation in the country which has caused frequent floods and erosion of top soil and in to river system.

The key areas to be considered have to adopt mix and match techniques for sustainable building construction. Sustainability in architecture and building construction can be obtained by improving the:

- Structure and architecture design

- Energy consumption during construction and operation phase

- Geometry and orientation of building

- Construction material 


\section{- Construction process}

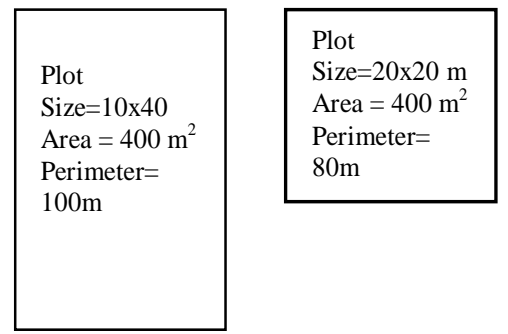

Fig. 18. Shapes of plot affect the cost of construction.

Looking the history of the region for earthquake and other natural disasters, building designs need to be refined and updated according to new type of loading (earthquake loading), which was considered previously negligible. But at present we have to use the horizontal loading and the factor of safety applied to these loads in the designing purpose will be dependent upon the statistical analysis of the historical earthquake data in the regions.

Geometry matters a lot in sustainability and over all construction cost of the building construction. . If a housing scheme is going to be constructed and instead of rectangular plot, square plot are given then the covered area remains the same but perimeter of square is 20 percent lesser. In this case overall cost of construction may be reduced by the 30 percent shown in Figure 20 below.

Building incurred by horizontal effect of earthquake have tendency to shift direction level off and rotate. So that, it is important to separate buildings being two part or more in form building lay out and constructions. In order to the times of earthquake, each share vibrates according to its time. This concept can mix with traditional green architectural concepts. The house will be safer and lesser cost. Lesser cost means the house can build part by part, according to their needs. Examples lay out shown in figure 21 below:

1.

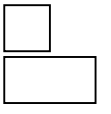

2.

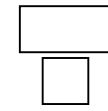

3.

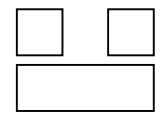

Fig. 19. Form building layout with consist of severalbuildings will be safer and lesser cost

Two story houses give the lesser cost compare to single unit. The construction cost and use of raw material can be further reduced by reducing the story height.

Perceive with floods disaster and also keep cool the house naturally, raised-floor structure and construction can use to the modern housing. Energy efficiency also can reach to the house with raised-floor construction. Besides that, mixing concept raised-floor construction on single storey building is make ventilation in the bottom and up the wall. It will maximally the cross ventilation inside the house. 
Raised-floor construction also can give result for humidity problem in humid tropic area like Indonesia. (Figure 23) Humid tropic climate have much water in the air. Building always to absorb water from the air especially that was used from brick and tile brick.

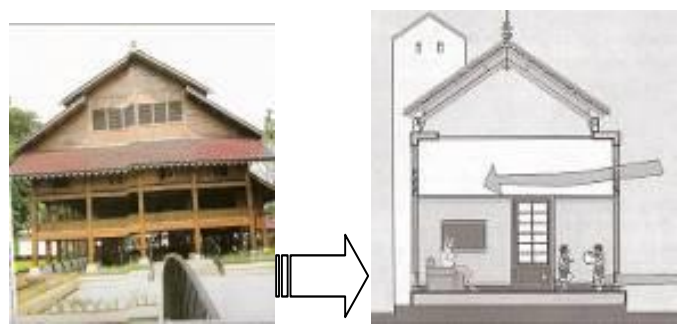

Fig. 20. Mix and match concepts form from traditional to modern house single story building.

House that stands up directly to the earth will to penetrate water into the wall. The moistness will influence the room if the wall was satiated with water, to result in grown of mushrooms in the wall. Construction phase is mainly dependent on design and the workmanship on site. Construction phase may be made more sustainable and efficient by improving construction methods and improving the process of construction.

The design process impact on the material type of material selected for construction. During construction phase a lot of energy is wasted during transportation of materials from longer distances. Therefore a lot of energy and resources can be saved by avoiding transportation of building material from longer distances and using locally available building material, which appeared in the Use of Natural Resources.

The wood used in most of the traditional construction, which can be adopted in the modern construction after recycles. Wood, already used or weathered by weathering agent can be easily recycled. The ones of local / traditional material construction, beside wood which had proved tolerance with earthquake is bamboo. However now in the world, there are many buildings construction from bamboo in modern technology. Mixing construction concept between bamboos with modernengineering technology is according to sustainable architecture principle.

Substitute material is the material which it can substitution natural materials. Use the substitute material in the right place will take an advantage of this material. Material composite is the material substitution that at presents is solution to mixing the traditional and local material with modern technology. The example materials are gypsum, plywood, glass fiber reinforced cement (GRC), calsiboard, glass fiber reinforce plastic (GFRP), fiber reinforced polymer (FRP), etc. Composite materials are having flexibility in design, energy efficiency, easy in assembly, mass product and low cost.

Introduction of composite structure members can be used to increase the strength and working capacity of material. E.g. wood beam with iron patches in the centre of the beam to increase the resisting bending moment of the wood and that way cheaper wood can be utilized with improved structure characteristics. .

Indonesia compromising of the islands and most of the population are in the coast region where the speed of wind is higher than the inner part of the islands. Therefore advantage of wind energy is to convert that in electrical or other form of energy that can be used by the housing sector. As the system is costly and extensive research is needed to find the wind 
velocity to locate location of wind turbine stations. Therefore experimentally, it can be introduces in comparatively bigger islands like Java Sumatra and Kalimantan.

Solar energy can be used for conversion of electrical energy by using photovoltaic cells arrangements on inclined roofs. It is no doubt costly in the start but will going to save 10 times more during its operations phase of the building.Orientation can be optimized depending upon site conditions and over all topography of the region.

Traditional insulation techniques are more economical and efficient used in tropics therefore traditional insulation techniques can be used in modern building construction.

\section{Conclusion}

Housing settlement with mix and match traditional \& modern technology is not only cost effective and resistant to natural hazards but will also help to maintain a concept of traditional architecture in the region. The innovation in design and construction coupled with mix and match technique will leads towards the ideology of sustainable development in the housing sector. Modern Housing Architecture which is designed with mix and match traditional and modern technology is progressively required towards sustainable architectural settlements in tropics. This also requires the fully support from government as policy determinant, and integrated design from architect, engineer and planer. Governments as policy determinant have to apply national standards for planning and construction composite material which can adapted by condition and material availability, so that the industries can give amenity and efficiency in development of houses on the area.

\section{References}

[1]Brundland Commision, "Sustainable Architechture," 1987.

[2]Future Arc, "Learning from experience," 2006.

[3]A. Sugandi, "Seminar Nasional Arsitektur," 2007.

[4]U. Siahaan, "International Seminar of Green Architecture Proceding," 2006.

[5]Mendler, S. F, and W. Odell., The HOK Guidebook to Sustainable Design. New York: Wileyle, 2000.

[6]Stephen M. Wheeler, Planning for Sustainability,. Roudledge, 2004.

[7]International Monetary Fund, "Estimate World Economic Outlook Database Press release. Retrieved on 2006-10-05.; Indonesia Regions. Indonesia Business Directory. Retrieved on 24-04-2007,” 2006.

[8]Lester and Brown, State of the World 1997: A Worldwatch Institute Report on Progress Toward a Sustainable Society (14th edition). New York: W. W. Norton \& Company, page 7. ISBN-0393040089. New York: W. W. Norton \& Company, 2007.

[9]Globalis-Indonesia., "Globalis, an interactive world map," 2014.

[10]Witton and Patrick, Indonesia. Melbourne: Lonely Planet, 2003.

[11]Wangsadinata, W. Djajasudarma, and T.K., "Architectural Design Consideration for Modern Buildings in Indonesia," 2007.

[12]B. Dawson and J. Gillow, The Traditional Architecture of Indonesia. London: Thames and Hudson, 1994.

[13]T. P. Utomo and S. Subiantoro, "Nilai Kearifan Lokal Rumah Tradisional Jawa," Humaniora, vol. 24, no. 3, pp. 269-278, 2012.

[14]N. S. Maulana Abdulah, Antariksa, "Pola Ruang Dalam Bangunan Rumah Gadang,” J. Mhs. Jur. Arsit. UB, vol. 3, no. 1, 2015.

[15]R. Budiharjo, “Konsep Arsitektur Bali Aplikasinya pada bangunan Puri," Nalars, vol. 1, pp. 17-42, 2013.

[16]Ir. Soekarno, Dibawah Bendera Revolusi. Panitia, 1963. 
